\title{
Связь способов поведения в конфликте с типами защитного и совладающего поведения юношей и девушек
}

\author{
Ирина В. Борисова“, Юлия Н. Хадыкина \\ Брянский государственный университет имени академика И.Г. Петровского, г. Брянск, \\ Российская Федерация \\ *E-mail: Irmarbor1@yandex.ru
}

\begin{abstract}
Аннотация
Ввеление. Авторами обосновывается актуальность изучения связи поведения в конфмикте с типами защитного и совлаАающего поведения юношей и Аевушек. Рассматриваются работы отечественных и зарубежных психологов, направленные на изучение конфликта, механизмов психологической защиты и способов совладающего поведения. Новизна исследования состоит в том, что способы поведения в конффиикте рассматриваются в связи с типами защитного и сов^аАающего поведения юношей и Аевушек.
\end{abstract}

Материалы и методы. В разделе представлены данные о выборке: в исследовании приняли участие 39 человек (23 юноши и 16 девушек), учащиеся 10-11 классов средней школы п. Аюбохны Брянской области. Описываются использованные методики: «ИнАекс жизненного стиля» Р. Плутчика, «Способы совлаАающего поведения» Р. Аазаруса, «Способы поведения в конфликте» К. Томаса.

Результаты. В Аанном разделе приводятся результаты эмпирического исслеАования связи способов поведения в конфАикте с типами защитного и совлаАающего поведения юношей и Аевушек. Описываются статистически значимые различия в системе защитного и совлаАающего поведения в труАной стрессовой ситуации юношей и девушек. Рассматриваются связи способов поведения в конффикте с защитным и совладающим поведением юношей и девушек. В частности, выявлено, что стратегия сотрудничества в конорликте у юношей имеет прямую связь с принятием ответственности и поиском социальной подАержки, у Аевушек - обратную Связь С коноронтативным копингом и самоконтролем.

Обсужаение результатов. Авторы рассматривают психологическую защиту, совладающее поведение, способы поведения в конфликте и связи межАу перечисленными компонентами у юношей и девушек. Способы поведения в конфликте юношей и девушек имеют разные связи с механизмами психологической защиты и стратегиями сов^адающего поведения. Полученные результаты исслеАования можно использовать Аля оказания психологической помощи юношам и Аевушкам. 


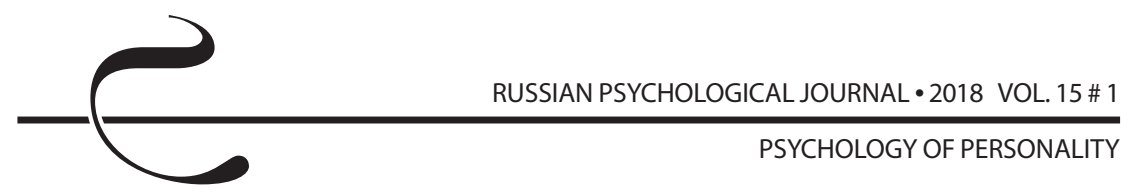

\title{
КАючевые слова
}

конфрликт, способы повеАения в конфрликте, защитное повеАение, психологическая защита, механизмы психологической защиты, совладающее поведение, стратегии совладающего поведения, юноши, Аевушки, трудная стрессовая ситуация

\section{Основные положения}

- защитное и совлаАающее поведение в трудной стрессовой ситуации юношей и девушек имеют как общие тенденции, так и специорические различия;

- юноши и Аевушки чаще проявляют компромисс и реже соперничество по сравнению с Аругими способами поведения в конорликте;

- у юношей поведение в конфликте чаще связано со стратегиями совладающего поведения, а у девушек - с механизмами психологической защиты.

\section{Для цитирования}

Борисова И. В., Хадыкина Ю.Н. Связь способов поведения в конфликте с типами защитного и совладающего поведения юношей и девушек // Российский психологический журнал. - 2018. - T. 15, № 1. - C. 92-112. DOI: 10.21702/rpj.2018.1.5

Материалы статьи получены 30.04.2017

UDC 159.922 .8

DOI: $10.21702 /$ rpj.2018.1.5

\section{Strategies of Behavior in Conflicts, Coping strategies, and Defense Mechanisms Among Adolescent Boys and Girls}

\section{Irina V. Borisova*, Yuliya N. Khadykina}

Petrovsky Bryansk State University, Bryansk, Russian Federation

*Correspondence author. E-mail: Irmarbor1@yandex.ru

\begin{abstract}
Introduction. The present paper overviews domestic and foreign studies on conflicts, psychological defense mechanisms, and coping strategies. The novelty of the research lies in studying the relationships among the strategies of behavior in conflicts, coping strategies, and psychological defense mechanisms among adolescent boys and girls.
\end{abstract}

Materials and Methods. These were the Life Style Index questionnaire (R. Plutchik); the Ways of Coping Questionnaire (WCQ) (R. Lazarus); The Thomas-Kilmann Conflict Mode Instrument (TKI). The study involved 23 boys and 16 girls, tenth and eleventh grade secondary school students in Lyubokhna, Bryansk region. 
Results. The study revealed a statistically significant difference in coping strategies and psychological defense mechanisms in difficult or stressful situations among adolescent boys and girls. The strategy of cooperation in conflict situations had a direct relationship with accepting responsibility and seeking social support in the group of adolescent boys. The strategy of cooperation in conflict situations had an inverse relationship with confrontational coping and self-controlling in the group of adolescent girls.

Discussion. Adolescent boys and girls differ in how their strategies of behavior in conflicts are associated with coping strategies and defense mechanisms. The findings are useful for providing psychological assistance to adolescent boys and girls.

\section{Keywords}

conflict, strategies of behavior in conflicts, defensive behavior, psychological defense, psychological defense mechanisms, coping behavior, coping strategies, adolescent boys, adolescent girls, difficult stressful situation

\section{Highlights}

- Defense mechanisms and coping strategies in difficult stressful situations are characterized by both general tendencies and differences among adolescent boys and girls.

- Adolescent boys and girls demonstrate compromise most often in conflict situations; they demonstrate rivalry least often.

- Adolescent boys' strategies of behavior in conflicts are associated with coping strategies; adolescent girls' strategies of behavior in conflicts are associated with psychological defense mechanisms.

\section{For citation}

Borisova I.V., Khadykina Yu. N. Strategies of Behavior in Conflicts, Coping strategies, and Defense Mechanisms Among Adolescent Boys and Girls. Rossiiskii psikhologicheskii zhurnal - Russian Psychological Journal, 2018, V. 15, no. 1, pp. 92-112 (in Russian). DOI: 10.21702/rpj.2018.1.5

Original manuscript received 30.04.2017

\section{Введение}

Интерес к теоретическому и практическому исследованию конфликта в настоящее время объясняется усилением конфликтности и напряженности в различных сферах общественной и личной жизни, в которую активно включаются юноши и девушки. Изучением различных аспектов проблемы конфликта занимались зарубежные и отечественные психологи: 3. Фрейд [1], У. Томас [2], М. Дойч [3], Р. Фишер, У. Юри [4], А.Я. Анцупов, А. И. Шипилов [5], Н.В. Гришина [6], и др. 


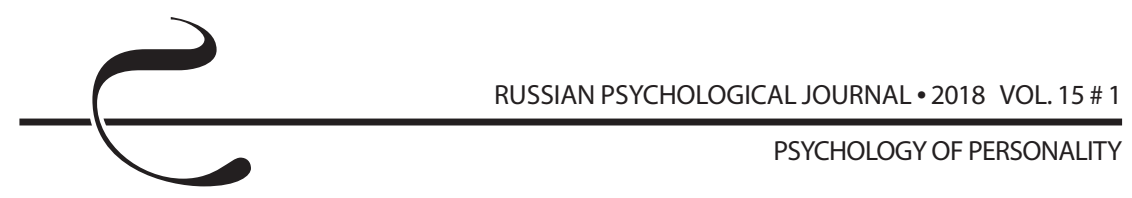

Большой вклад в развитие проблемы защитного поведения внесли работы 3. Фрейда [1], А. Фрейд [7], Р. Плутчика, Г. Келлермана [8], Ф.В. Бассина [9], Р.М. Грановской, И.М. Никольской [10], Е.С. Романова, Л.Р. Гребенникова [11] и др., в изучение совладающего поведения - работы Р. Лазаруса, С. Фолкмана [12, 13], Д. Амирхана [14], Э. Фрайденберг [15], В.М. Ялтонского, Н. А. Сироты [16], Т.Л. Крюковой [17] и др. В настоящее время интерес к изучению различных аспектов проблемы защитного и совладающего поведения растет [18, 19, 20, 21, 22 и др.]. Нами ранее изучалось совладающее поведение студентов с разной тревожностью [23], пенсионеров с разным гендерным полом [24], работников поликлиники [25], женщин с разной сексуальной ориентацией и гендерной идентичностью [26], защитное и совладающее поведение юношей и девушек из полных и неполных семей $[27,28]$.

Юношеский возраст считается важным этапом в развитии личности и является переходным периодом от зависимого детства к самостоятельной взрослости [29, 30].

Несмотря на большое количество работ, посвященных конфликту, психологической защите и совладающему поведению, взаимосвязь способов поведения в конфликте с типами защитного и совладающего поведения юношей и девушек остается малоизученной и актуальной проблемой в настоящее время. Целью данного исследования является изучение связи способов поведения в конфликте с типами защитного и совладающего поведения юношей и девушек.

Психологическую защиту будем рассматривать как специальную систему стабилизации личности, которая ограждает сознание от неприятных, травмирующих переживаний, сопряженных с внешними и внутренними конфликтами, состояниями тревоги и дискомфорта. Психологическая защита включается неосознанно в трудной стрессовой ситуации. При включении защиты психические процессы личности работают таким образом, что неприятная информация либо игнорируется, либо искажается, либо фальсифицируется, позволяя личности сохранить должное самоуважение [10].

Под совладающим поведением в настоящем исследовании мы будем понимать целенаправленное социальное поведение, позволяющее субъекту справиться с трудной жизненной ситуацией (или стрессом) способами, адекватными личностным особенностям и ситуации, через осознанные стратегии действий [17].

Гипотеза исследования состояла в том, что юноши и девушки имеют различия в способах поведения в конфликте, в защитном и совладающем поведении. Способы поведения в конфликте юношей и девушек имеют разные связи с защитным и совладающим поведением. 


\section{Материалы и методы}

В исследовании приняли участие 39 человек (23 юноши и 16 девушек), учащиеся 10-11 классов средней школы п. Любохны Брянской области. Для достижения цели исследования и проверки выдвинутой гипотезы использовались методики: «Индекс жизненного стиля» Р. Плутчика, «Способы совладающего поведения» Р. Лазаруса, «Способы поведения в конфликте» К. Томаса. Статистическая обработка результатов исследования осуществлялась с помощью критерия Манна - Уитни и критерия корреляции Пирсона.

\section{Результаты}

Типы психологической защиты юношей и девушек представлены в таблице 1 и на рисунке 1.

Таблица 1. Психологическая защита юношей и девушек

Table 1. Psychological defense mechanisms among adolescent boys and girls

\begin{tabular}{|c|c|c|c|}
\hline $\begin{array}{c}\text { Типы психологической } \\
\text { защиты } \\
\text { Psychological defense } \\
\text { mechanisms }\end{array}$ & $\begin{array}{c}\text { Юноши } \\
\text { Adolescent } \\
\text { boys } \\
n_{1}=23 \\
\end{array}$ & $\begin{array}{c}\text { Аевушки } \\
\text { Adolescent } \\
\text { girls } \\
n_{2}=16 \\
\end{array}$ & $\begin{array}{c}\text { Аостоверность } \\
\text { различий } \\
\text { Statistical } \\
\text { significance }\end{array}$ \\
\hline $\begin{array}{l}\text { Отрицание } \\
\text { Denial }\end{array}$ & 51,2 & 54,3 & 160,5 \\
\hline $\begin{array}{l}\text { Подавление } \\
\text { Repression }\end{array}$ & 52,5 & 42,7 & 139,5 \\
\hline $\begin{array}{l}\text { Регрессия } \\
\text { Regression }\end{array}$ & 39,1 & 53,1 & $111,0^{*}$ \\
\hline $\begin{array}{l}\text { Компенсация } \\
\text { Compensation }\end{array}$ & 47,2 & 56,3 & 138,5 \\
\hline $\begin{array}{l}\text { Проекция } \\
\text { Projection }\end{array}$ & 60,7 & 66,3 & 139,0 \\
\hline $\begin{array}{l}\text { Замещение } \\
\text { Displacement }\end{array}$ & 37,5 & 50,5 & 122,0 \\
\hline $\begin{array}{l}\text { Интел^ектуализация } \\
\text { Intellectualization }\end{array}$ & 58,7 & 64,1 & 157,0 \\
\hline $\begin{array}{l}\text { Реактивное образование } \\
\text { Reaction formation }\end{array}$ & 48,3 & 73,8 & $87,0 * *$ \\
\hline $\begin{array}{l}\text { Общая напряженность } \\
\text { психологической защиты } \\
\text { General tension of psy- } \\
\text { chological defense }\end{array}$ & 49,3 & 57,1 & $90,0 * *$ \\
\hline
\end{tabular}

Примечание: * различия статистически достоверны при $\leq \leq 0,05$; ** различия статистически достоверны при $p \leq 0,01$.

Note: * at the 0.05 level of significance; ${ }^{* *}$ at the 0.01 level of significance. 

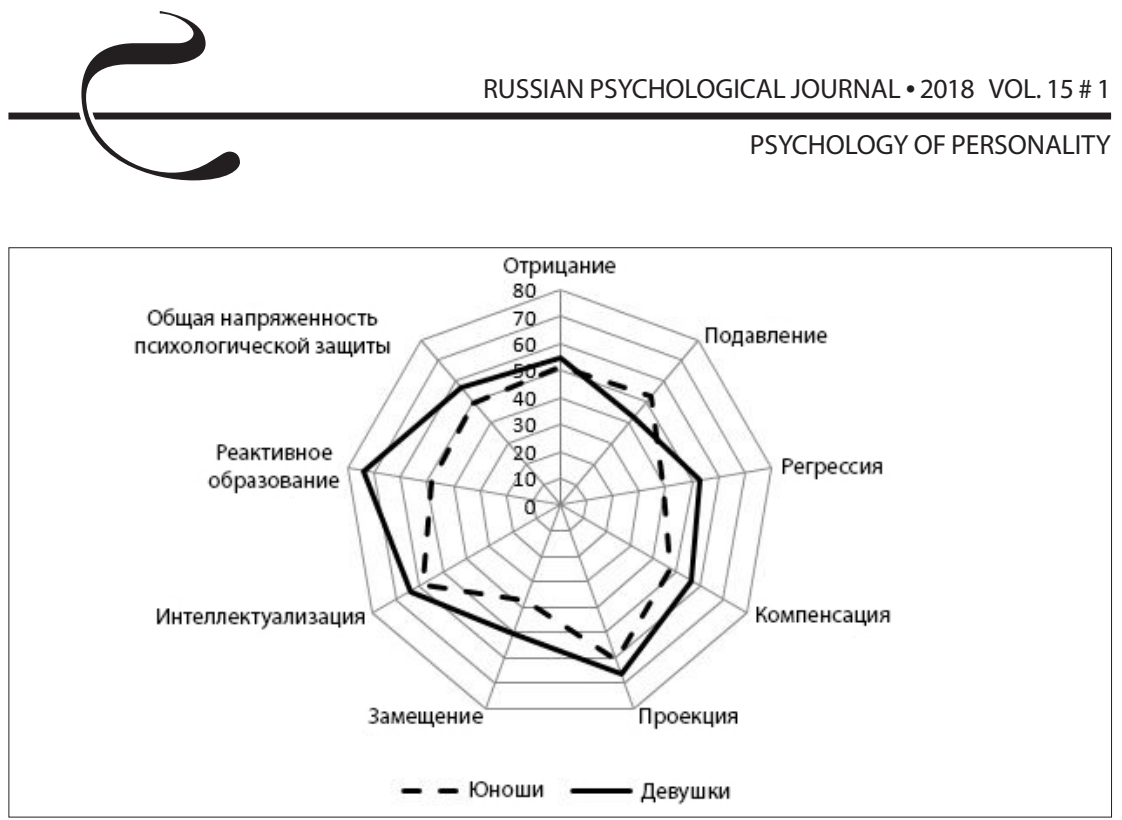

Рисунок 1. Профри^ь психологической защиты юношей и девушек

Figure 1. A profile of defense mechanisms among adolescent boys and girls

Как видно из таблицы 1 и рисунка 1, среди механизмов психологической защиты у юношей более выражены проекция и интеллектуализация, которые относят к зрелым механизмам защиты, и менее выражены замещение и регрессия, которые относят к примитивным механизмам защиты. У девушек более выражено реактивное образование, относящееся к примитивным механизмам, а также проекция и интеллектуализация, принадлежащие к зрелым способам защиты, и менее выражено подавление, считающееся примитивным механизмом.

Юноши чаще, чем девушки, проявляют подавление и реже - все остальные типы психологической защиты. Подавление относят к примитивным механизмам защиты, оно состоит в блокировании неприятной информации при ее выводе из памяти в сознание. Общая напряженность психологической защиты более выражена у девушек, чем у юношей.

Обнаружены статистически значимые различия между юношами и девушками в проявлении регрессии, реактивного образования и общей напряженности психологической защиты. Девушки чаще, чем юноши, возвращаются к поведению, характерному для более раннего возраста, изменяют неприятные или неприемлемые для них мысли, чувства или поступки на сильные противоположные стремления, и в целом у них более выражена психологическая защита в трудных стрессовых ситуациях.

Результаты нашего исследования согласуются с результатами, полученными при адаптации методики «Индекс жизненного стиля» Р. Плутчика на 
российской выборке студентов. Е.С. Романова, Л.Р. Гребенников обнаружили, что юноши значимо чаще используют подавление, а девушки значимо чаще - реактивное образование [11].

Типы совладающего поведения юношей и девушек представлены в таблице 2 и на рисунке 2.

Таблица 2. Совлалающее поведение юношей и девушек

Table 2. Coping strategies among adolescent boys and girls

\begin{tabular}{|c|c|c|c|}
\hline $\begin{array}{c}\text { Типы совладающего } \\
\text { поведения } \\
\text { Coping strategies }\end{array}$ & $\begin{array}{c}\text { Юноши } \\
\text { Adolescent } \\
\text { boys } \\
n_{1}=23\end{array}$ & $\begin{array}{c}\text { Аевушки } \\
\text { Adolescent } \\
\text { girls } \\
n_{2}=16\end{array}$ & $\begin{array}{c}\text { Аостоверность } \\
\text { различий } \\
\text { Statistical } \\
\text { significance }\end{array}$ \\
\hline $\begin{array}{l}\text { Коноронтация } \\
\text { Confronting coping }\end{array}$ & 44,7 & 41,9 & 167,5 \\
\hline $\begin{array}{l}\text { Аистанцирование } \\
\text { Distancing }\end{array}$ & 44,7 & 47,6 & 170,5 \\
\hline $\begin{array}{l}\text { Самоконтроль } \\
\text { Self-controlling }\end{array}$ & 53,6 & 50,0 & 164,0 \\
\hline $\begin{array}{l}\text { Поиск социальной } \\
\text { полАержки } \\
\text { Seeking social support }\end{array}$ & 44,0 & 51,4 & 148,0 \\
\hline $\begin{array}{l}\text { Принятие } \\
\text { ответственности } \\
\text { Aсcepting responsibility }\end{array}$ & 63,0 & 56,8 & 152,5 \\
\hline $\begin{array}{l}\text { Бегство-избегание } \\
\text { Escape-avoidance }\end{array}$ & 39,7 & 53,7 & $73^{* *}$ \\
\hline $\begin{array}{l}\text { П^анирование реше- } \\
\text { ния проблемы } \\
\text { Planful problem-solving }\end{array}$ & 59,7 & 57,3 & 158,5 \\
\hline $\begin{array}{l}\text { Положительная } \\
\text { переоценка } \\
\text { Positive reappraisal }\end{array}$ & 47,6 & 52,7 & 144,5 \\
\hline
\end{tabular}

Примечание: ** различия статистически достоверны при $p \leq 0,01$.

Note: ${ }^{* *}$ at the 0.01 level of significance. 

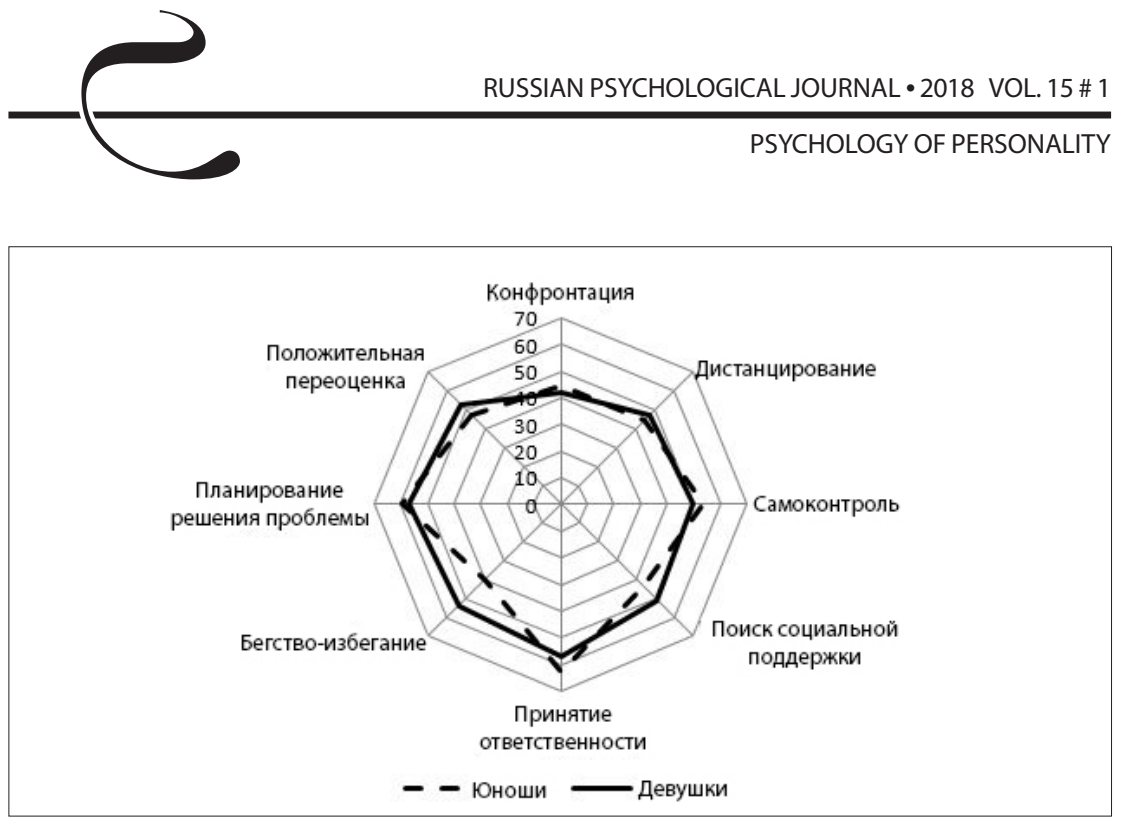

Рисунок 2. Профриль совладающего поведения юношей и Аевушек

Figure 2. A profile of coping strategies among adolescent boys and girls

Как видно из таблицы 2 и рисунка 2, юноши среди типов совладающего поведения чаще проявляют принятие ответственности, планирование решения проблемы, самоконтроль, положительную самооценку, и реже - бегствоизбегание, поиск социальной поддержки, дистанцирование, конфронтацию. Девушки среди типов совладающего поведения чаще используют планирование решения проблемы, принятие ответственности, бегство-избегание, положительную самооценку, и реже - конфронтацию, дистанцирование, самоконтроль, поиск социальной поддержки.

У юношей, по сравнению с девушками, более выражены конфронтация, самоконтроль, принятие ответственности, планирование решения проблемы, менее выражены дистанцирование, поиск социальной поддержки, бегствоизбегание, положительная переоценка. У юношей больше положительных и условно положительных стратегий поведения и меньше отрицательных, по сравнению с девушками. Установлены статистически значимые различия между юношами и девушками в проявлении стратегии бегства-избегания, которая выражается в попытках улучшения своего самочувствия путем принятия еды, алкоголя, курения.

Типы поведения в конфликте юношей и девушек представлены в таблице 3 и на рисунке 3. 
Таблица 3. Поведение юношей и девушек в кондрикте

Table 3. Strategies of behavior in conflicts among adolescent boys and girls

\begin{tabular}{|c|c|c|c|}
\hline $\begin{array}{l}\text { Типы поведения } \\
\text { в конффиикте } \\
\text { Strategies of } \\
\text { behavior in conflicts }\end{array}$ & $\begin{array}{c}\text { Юноши } \\
\text { Adolescent } \\
\text { boys } \\
n_{1}=23\end{array}$ & $\begin{array}{c}\text { Аевушки } \\
\text { Adolescent } \\
\text { girls } \\
n_{2}=16\end{array}$ & $\begin{array}{c}\text { Аостоверность } \\
\text { размичий } \\
\text { Statistical significance }\end{array}$ \\
\hline $\begin{array}{l}\text { Соперничество } \\
\text { Rivalry }\end{array}$ & 3,9 & 5,5 & 132,0 \\
\hline $\begin{array}{l}\text { Сотрудничество } \\
\text { Cooperation }\end{array}$ & 5,8 & 5,8 & 178,0 \\
\hline $\begin{array}{l}\text { Компромисс } \\
\text { Compromise }\end{array}$ & 7,6 & 7,1 & 153,0 \\
\hline $\begin{array}{l}\text { Избегание } \\
\text { Avoidance }\end{array}$ & 5,9 & 5,9 & 171,0 \\
\hline $\begin{array}{l}\text { Приспособление } \\
\text { Adaptation }\end{array}$ & 6,8 & 5,5 & 132,0 \\
\hline
\end{tabular}

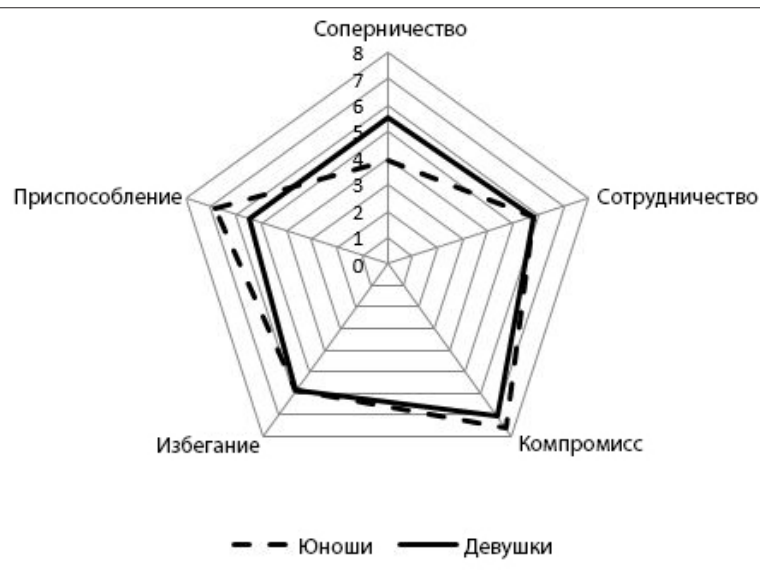

Рисунок 3. Проффиль поведения в конфриикте юношей и девушек

Figure 3. A profile of strategies of behavior in conflicts among adolescent boys and girls 


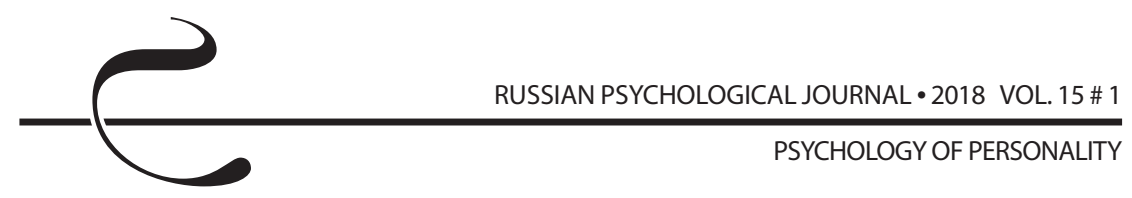

Как видно из таблицы 3 и рисунка 3, юноши чаще проявляют компромисс (высокий уровень) и реже - соперничество (низкий уровень), по сравнению с другими способами поведения. Девушки чаще проявляют компромисс (высокий уровень), и реже - соперничество (средний уровень) и приспособление (средний уровень).

У юношей более выражены компромисс и приспособление, и менее выражено соперничество, по сравнению с девушками. Сотрудничество и избегание у юношей и девушек выражены одинаково. Статистически значимых различий не установлено.

Полученные результаты показали, что и юноши и девушки владеют разными стратегиями поведения в конфликте и могут применять наиболее подходящие стратегии в зависимости от конкретной ситуации. Установлено, что и юноши и девушки в конфликте чаще всего используют компромисс, т. е. стараются договориться со сверстниками и взрослыми и готовы поступиться частью своих интересов ради сохранения отношений с противоположной стороной конфликта. Реже других стратегий поведения и юноши и девушки используют соперничество, которое не учитывает интересы другой стороны в конфликте. Различия в использовании стратегий поведения в конфликте испытуемыми мужского и женского пола не выявлено.

Значимые корреляционные связи между типами поведения в конфликте и способами защитного и совладающего поведения юношей представлены в таблице 4.

Как видно из таблицы 4, установлена прямая связь между сотрудничеством и компенсацией $(r=0,418 ; p \leq 0,05)$, сотрудничеством и поиском социальной поддержки ( $r=0,418 ; p \leq 0,05)$, сотрудничеством и принятием ответственности ( $r=0,605 ; p \leq 0,01)$, компромиссом и интеллектуализацией $(r=0,639 ; p \leq 0,01)$, компромиссом и поиском социальной поддержки $(r=0,530 ; p \leq 0,05)$, приспособлением и отрицанием $(r=0,509 ; p \leq 0,05)$, приспособлением и самоконтролем $(r=0,560 ; p \leq 0,01)$, и обратная связь между соперничеством и самоконтролем ( $r=-0,494 ; p \leq 0,05)$, избеганием и общей напряженностью психологических защит ( $r=-0,458 ; p \leq 0,05)$, приспособлением и принятием ответственности ( $r=-0,454 ; p \leq 0,05)$. Сотрудничество и приспособление имеют наибольшее количество связей с защитным и совладающим поведением.

Чем более выражено сотрудничество в конфликте, тем сильнее у юношей неосознанное отождествление своих качеств с положительными качествами другого человека, сознательные усилия в поиске эмоциональной, информационной и действенной поддержки, активные попытки решения проблемы. 
пСИхология личности

Таблица 4. Значимые корреляционные связи межАу типами поведения в конффикте и способами защитного и совладающего поведения юношей

Table 4. Significant correlations among strategies of behavior in conflicts, coping strategies, and defense mechanisms among adolescent boys

\begin{tabular}{|c|c|c|}
\hline $\begin{array}{l}\text { Типы поведения } \\
\text { в конфмикте } \\
\text { Strategies of } \\
\text { behavior in conflicts }\end{array}$ & $\begin{array}{c}\text { Защитное и совладающее поведение } \\
\text { Coping strategies and defense } \\
\text { mechanisms }\end{array}$ & $\begin{array}{l}\text { r Пирсона } \\
\text { Pearson's r }\end{array}$ \\
\hline $\begin{array}{c}\text { Соперничество } \\
\text { Rivalry } \\
\end{array}$ & $\begin{array}{l}\text { Самоконтроль* } \\
\text { Self-controlling* }\end{array}$ & $-0,494$ \\
\hline $\begin{array}{c}\text { Сотрудничество } \\
\text { Cooperation }\end{array}$ & $\begin{array}{c}\text { Компенсация* } \\
\text { Compensation* } \\
\text { Поиск социальной подлержки* } \\
\text { Seeking social support* } \\
\text { Принятие ответственности** } \\
\text { Асcepting responsibility** }\end{array}$ & $\begin{array}{l}0,418 \\
0,483 \\
0,605\end{array}$ \\
\hline $\begin{array}{l}\text { Компромисс } \\
\text { Compromise }\end{array}$ & $\begin{array}{c}\text { Интелмектуализация** } \\
\text { Intellectualization** } \\
\text { Поиск социальной подлержки** } \\
\text { Seeking social support** }\end{array}$ & $\begin{array}{l}0,639 \\
0,530\end{array}$ \\
\hline $\begin{array}{l}\text { Избегание } \\
\text { Avoidance }\end{array}$ & $\begin{array}{c}\text { Общая напряженность психологиче- } \\
\text { ской защиты* } \\
\text { General tension of psychological } \\
\text { defense* }\end{array}$ & $-0,458$ \\
\hline $\begin{array}{c}\text { Приспособление } \\
\text { Adaptation }\end{array}$ & $\begin{array}{c}\text { Отрицание* } \\
\text { Denial* } \\
\text { Cамоконтроль** } \\
\text { Self-controlling** } \\
\text { Принятие ответственности* } \\
\text { Асcepting responsibility* }\end{array}$ & $\begin{array}{r}0,560 \\
-0,454\end{array}$ \\
\hline
\end{tabular}

Примечание: ${ }^{* *}$ коррелячия при $p \leq 0,01 ;{ }^{*}$ коррелячия при $p \leq 0,05$.

Note: ${ }^{* *}$ correlation at the $p \leq 0.01$ level; * correlation at the $p \leq 0.05$ level.

Чем более выражен компромисс как способ поведения в конфликте, тем сильнее юноши пытаются бессознательно оправдать случившееся путем построения убедительных доводов и предпринять больше сознательных усилий в поиске эмоциональной, информационной и действенной поддержки.

Чем выше избегание как способ поведения в конфликте, тем слабее психологическая защита юношей. 
Чем более выражено приспособление, тем сильнее у юношей бессознательное игнорирование потенциально тревожной информации, усилия по контролированию своих эмоций и действий, анализ проблемы, поиск путей выхода из сложившейся ситуации, и тем меньше активные попытки решения проблемы.

Чем выше соперничество в конфликте, тем меньше усилий предпринимают юноши по контролированию своих эмоций и действий, по анализу проблемы и поиску путей выхода из сложившейся ситуации.

Корреляционные плеяды типов поведения в конфликте юношей с защитным и совладающим поведением представлены на рисунке 4.

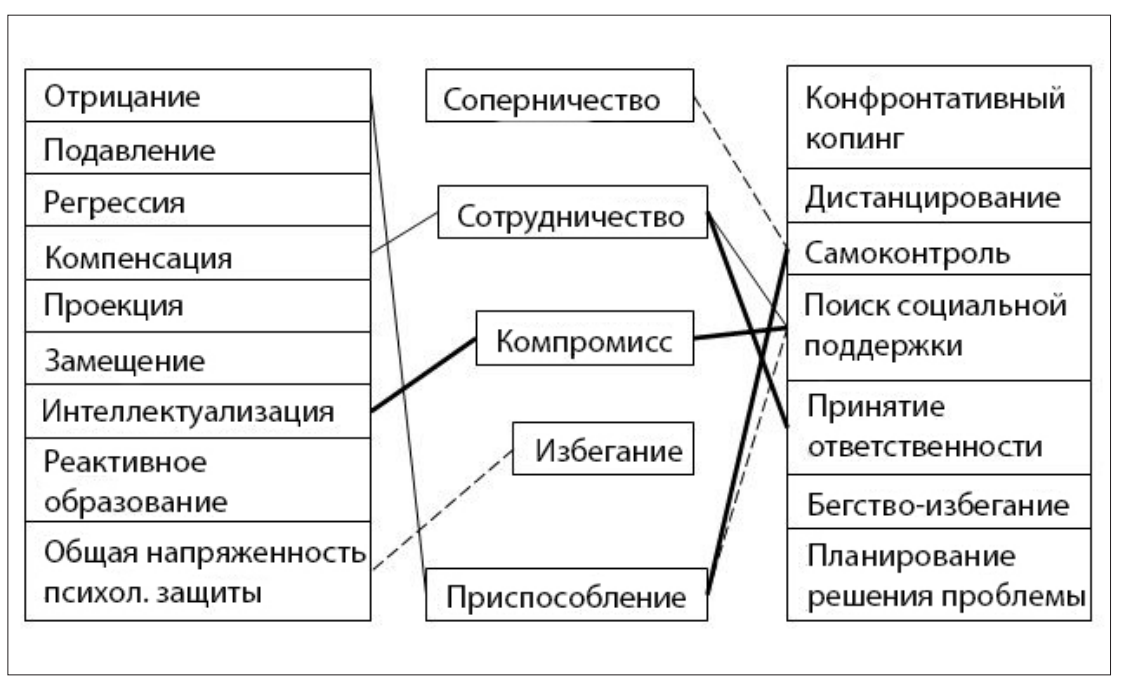

Рисунок 4. Корреляционные плеялы типов поведения в конффикте с защитным и совладающим поведением юношей

Условные обозначения:

- положительная корреляция, $p \leq 0,01$;

- положительная коррелячия, $p \leq 0,05$;

- - отрицательная коррелячия, $p \leq 0,05$.

Figure 4. Strategies of behavior in conflicts and coping strategies among adolescent boys (correlation pleiads)

Legend:

- Positive correlation, $p \leq 0.01$;

- Positive correlation, $p \leq 0.05$;

- - Negative correlation, $p \leq 0.05$. 
Значимые корреляционные связи между типами поведения в конфликте и способами защитного и совладающего поведения девушек представлены в таблице 5 .

Таблица 5. Значимые корреляционные связи межАу типами поведения в кондрмикте и способами защитного и совладающего поведения Аевушек

Table 5. Significant correlations among strategies of behavior in conflicts, coping strategies, and defense mechanisms among adolescent girls

\begin{tabular}{|c|c|c|}
\hline $\begin{array}{c}\text { Типы поведения } \\
\text { в конфмикте } \\
\text { Strategies of behavior in } \\
\text { conflicts }\end{array}$ & $\begin{array}{c}\text { Защитное и совладающее } \\
\text { поведение } \\
\text { Coping strategies and defense } \\
\text { mechanisms }\end{array}$ & $\begin{array}{l}r \text { Пирсона } \\
\text { Pearson's } r\end{array}$ \\
\hline $\begin{array}{c}\text { Соперничество } \\
\text { Rivalry }\end{array}$ & $\begin{array}{l}\text { Замещение** } \\
\text { Displacement** }\end{array}$ & 0,641 \\
\hline $\begin{array}{c}\text { Сотрудничество } \\
\text { Cooperation }\end{array}$ & $\begin{array}{l}\text { Конфрронтация* } \\
\text { Confronting соріng* } \\
\text { Самоконтроль* } \\
\text { Self-controlling* }\end{array}$ & $\begin{array}{l}-0,509 \\
-0,505\end{array}$ \\
\hline $\begin{array}{l}\text { Компромисс } \\
\text { Compromise }\end{array}$ & $\begin{array}{l}\text { Подавление* } \\
\text { Repression* } \\
\text { Замещение* } \\
\text { Displacement* }\end{array}$ & $\begin{array}{l}0,507 \\
-0,562\end{array}$ \\
\hline $\begin{array}{l}\text { Избегание } \\
\text { Avoidance }\end{array}$ & - & - \\
\hline $\begin{array}{c}\text { Приспособление } \\
\text { Adaptation }\end{array}$ & $\begin{array}{c}\text { Реактивное образование** } \\
\text { Reaction formation** }\end{array}$ & $-0,725$ \\
\hline
\end{tabular}

Примечание: ${ }^{* *}$ коррелячия при $p \leq 0,01 ;{ }^{*}$ коррелячия при $p \leq 0,05$.

Note: ${ }^{* *}$ correlation at the $p \leq 0.01$ level; * correlation at the $p \leq 0.05$ level.

Как видно из таблицы 5, установлена прямая связь между соперничеством и замещением ( $r=0,641 ; p \leq 0,01)$, между компромиссом и подавлением $(r=0,507 ; p \leq 0,05)$, и обратная связь между сотрудничеством и конфронтацией $(r=-0,509 ; p \leq 0,05)$, сотрудничеством и самоконтролем ( $r=-0,505$; $p \leq 0,05)$, компромиссом и замещением ( $r=-0,562 ; p \leq 0,05)$, приспособлением и реактивным образованием $(r=-0,725 ; p \leq 0,01)$. Связи избегания 
с защитным и совладающим поведением не выявлено. Сотрудничество и компромисс имеют наибольшее количество связей с типами защитного и совладающего поведения.

Чем выше выражено соперничество в конфликте, тем активнее девушки бессознательно разряжают подавленные эмоции на объектах, представляющих меньшую опасность, чем те, что вызвали отрицательные эмоции и чувства.

Чем выше сотрудничество в конфликте, тем меньше агрессивных усилий по изменению ситуации и действий, направленных на активное отстаивание своего мнения, желаний, а также попыток добиться своего предпринимают девушки, и тем ниже у них контроль за проявлением своих эмоций.

\begin{tabular}{|c|c|c|}
\hline Отрицание & Соперничество & \multirow{2}{*}{$\begin{array}{l}\text { Конфронтативный } \\
\text { копинг }\end{array}$} \\
\hline Подавление & \multirow{3}{*}{ Сотрудничество } & \\
\hline Регрессия & & Дистанцирование \\
\hline Компенсация & & Самоконтроль \\
\hline Проекция & \multirow[b]{2}{*}{ Компромисс } & \multirow{2}{*}{$\begin{array}{l}\text { Поиск социальной } \\
\text { поддержки }\end{array}$} \\
\hline Замещение & & \\
\hline Интеллектуализация & & Принятие \\
\hline Реактивное & \multirow[b]{3}{*}{ Приспособление } & ответственности \\
\hline образование & & Бегство-избегание \\
\hline $\begin{array}{l}\text { Общая напряженность } \\
\text { психол. защиты }\end{array}$ & & $\begin{array}{l}\text { Планирование } \\
\text { решения проблемы }\end{array}$ \\
\hline
\end{tabular}

Рисунок 5. Корреляционные плеялы типов поведения в конорликте с защитным и совладающим поведением Аевушек

Условные обозначения:

- положительная коррелячия, $p \leq 0,01$;

- положительная коррелячия, $p \leq 0,05$;

- -отрицательная коррелячия, $p \leq 0,01$;

- - отрицательная корреляция, $p \leq 0,05$.

Figure 5. Strategies of behavior in conflicts and coping strategies among adolescent girls (correlation pleiads)

Legend:

- Positive correlation, $p \leq 0.01$;

- Positive correlation, $p \leq 0.05$;

- Negative correlation, $p \leq 0.01$;

- Negative correlation, $p \leq 0.05$. 
Чем выше компромисс, тем сильнее девушки бессознательно блокируют в памяти неприятную информацию, и она становится недоступной для вывода в сознание, тем активнее девушки бессознательно разряжают подавленные эмоции на объектах, представляющих меньшую опасность, чем те, что вызвали отрицательные эмоции и чувства.

Чем выше приспособление, тем сильнее девушки изменяют неприятные или неприемлемые для них мысли, чувства или поступки на сильные противоположные стремления.

Корреляционные плеяды типов поведения в конфликте девушек с защитным и совладающим поведением представлены на рисунке 5.

Гипотеза исследования подтвердилась частично. Установлены значимые различия в защитном и совладающем поведении юношей и девушек; в способах поведения в конфликте юношей и девушек различий не выявлено. Установлены связи способов поведения в конфликте с защитным и совладающим поведением юношей и девушек.

\section{Обсуждение результатов}

Структура защиты юношей и девушек представлена разной выраженностью психологических механизмов. Юноши чаще используют проекцию, интеллектуализацию и реже - замещение, регрессию; девушки чаще используют реактивное образование, проекцию, интеллектуализацию и реже - подавление.

Психологическая защита, бессознательно включающаяся в трудной стрессовой ситуации, сильнее развита у девушек, чем у юношей. Юноши чаще, по сравнению с девушками, проявляют подавление, и реже - все остальные типы психологической защиты. Девушки значимо чаще используют регрессию и реактивное образование, чем юноши. Общий уровень напряженности психологической защиты значимо выше у девушек, по сравнению с юношами.

Совладающее поведение, сознательно реализуемое в трудной стрессовой ситуации, у юношей и девушек имеет как общие тенденции, так и существенные различия. Среди других стратегий поведения юноши чаще используют принятие ответственности, планирование решения проблемы и самоконтроль, а девушки - планирование решения проблемы, принятие ответственности и бегство-избегание. У юношей больше положительных и условно положительных стратегий поведения, и меньше отрицательных, по сравнению с девушками. Юноши значимо реже используют бегство-избегание, чем девушки.

Юноши и девушки в конфликте чаще используют компромисс, и реже соперничество. Достоверных различий в проявлении способов поведения в конфликте между юношами и девушками не выявлено. 


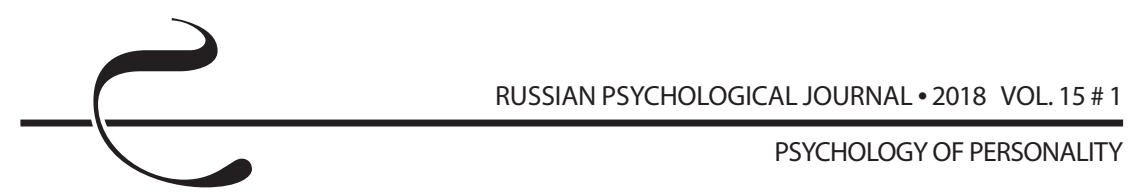

Способы поведения в конфликте у юношей имеют больше корреляций со стратегиями совладающего поведения, у девушек - с механизмами психологической защиты.

У юношей соперничество имеет обратную связь с дистанцированием, сотрудничество - прямую связь с компенсацией, принятием ответственности и поиском социальной поддержки, компромисс - прямую связь с интеллектуализацией и поиском социальной поддержки, избегание - обратную связь с общей напряженностью психологической защиты, приспособление - прямую связь с самоконтролем и обратную связь с поиском социальной поддержки.

У девушек соперничество имеет прямую связь с замещением, сотрудничество - обратную связь с конфронтацией и самоконтролем, компромисс - прямую связь с подавлением и обратную связь с замещением, приспособление - обратную связь с реактивным образованием. Связи избегания с защитным и совладающим поведением не установлено.

Полученные результаты исследования могут быть использованы практическими психологами для развития эффективной системы сознательного совладающего поведения юношей и девушек, помогающей справиться с трудностями и стрессами.

\section{Литература}

1. Фрейд 3. Психология бессознательного. - М. : Питер, 2007. - 400 с.

2. Thomas K. W. Conflict and negotiation // Handbook of Industrial and Organizational Psychology / M. D. Dunnette (Ed.). - Palo Alto, CA : Consulting Psychologists Press, 1992. - P. 889-935.

3. Deutsch M. Sixty years of conflict // International Journal of Conflict Management. - 1990. - Vol. 1, № 3. - P. 237-263. DOI: 10.1108/eb022682

4. Фишер Р., Юри У. Путь к согласию, или переговоры без поражения / пер. с англ. А. Гореловой. - М. : Наука, 1992. - 158 с.

5. Анцупов А. Я., Шипилов А. И. Конфликтология. - СПб. : Питер, 2013. - 512 с.

6. Гришина Н. В. Психология конфликта. - СПб. : Питер, 2008. - 544 с.

7. Фрейд А. Эго и механизмы психологической защиты. - М. : АСТ, 2008. 159 c.

8. Plutchik R., Kellerman H., Conte H.R. A structural theory of ego defenses and emotions // Emotions in personality and psychopathology / C. E. Izard (Ed.). N. Y. : Plenum Press, 1979. - P. 229-257.

9. Бассин Ф. В. О силе «Я» и «психологической защите» // Райгородский Д. Я. Самосознание и защитные механизмы личности : Хрестоматия. - Самара : Бахрах-М, 2008. - С. 3-15. - 656 с.

10. Грановская Р. М., Никольская И. М. Психологическая защита у детей. СПб. : Речь, 2010. - 352 с. 
11. Романова Е. С., Гребенников Л. Р. Механизмы психологической защиты: генезис, функционирование, диагностика. - Мытищи : Талант, 1996. - 144 c.

12. Lazarus R. S., Folkman S. Stress, Appraisal, and Coping. - N.Y. : Springer Publishing House, 1984. - 456 p.

13. Folkman S., Lazarus R. S. Coping as a mediator of emotion // Journal of Personality and Social Psychology. - 1998. - Vol. 54, Issue 3. - P. 466-475. DOI: 10.1037/0022-3514.54.3.466

14. Amirkhan J. H. A factor analytically derived measure of coping: The Coping Strategy Indicator // Journal of Personality and Social Psychology. - 1990. Vol. 59, Issue 5. - P. 1066-1074. DOI: 10.1037/0022-3514.59.5.1066

15. Frydenberg E. Coping Competencies: What to Teach and When // Theory Into Practice. - 2004. - Vol. 43, № 1. - P. 14-22.

16. Ялтонский В. М., Сирота Н. А. Психология совладающего поведения: развитие, достижения, проблемы, перспективы // Совладающее поведение: современное состояние и перспективы / под ред. А. Л. Журавлева, Т. Л. Крюковой, Е. А. Сергиенко. - М. : Изд-во ИП РАН, 2008. - С. 21-54.

17. Крюкова Т. Л., Гущина Т. В. Культура, стресс и копинг: социокультурная контекстуализация исследований совладающего поведения : Монография. - Кострома : Изд-во КГУ им. Н. А. Некрасова, 2015. - 236 с.

18. Давыдова М. О., Остапенко Р. И. Исследование связи оптимизма и совладающего поведения в период ранней взрослости // Перспективы науки и образования. - 2016. - Т. 21, № 3. - С. 76-81.

19. Gall T. L., Guirguis-Younger M. Religious and spiritual coping: Current theory and research // APA handbooks in psychology. APA handbook of psychology, religion, and spirituality (Vol. 1): Context, theory, and research / K. I. Pargament, J. J. Exline, J. W. Jones (Eds.). - Washington, DC : American Psychological Association, 2013. - P. 349-364. DOI: 10.1037/14045-019

20. Хачатурова М. Р. Совладающий репертуар личности: обзор зарубежных исследований // Психология. Журнал Высшей школы экономики. 2013. - Т. 10, № 3. - С. 160-169.

21. Бочавер К. А., ДовжикЛ. М. Совладающее поведение в профессиональном спорте: феноменология и диагностика // Клиническая и специальная психология. - 2016. - Т. 5, № 1. - С. 1-18. DOI: 10.17759/срse.2016050101

22. Безуглова А. А., Васильева О. С., Правдина Л. Р. Особенности социальнопсихологической адаптации у лиц с разными стратегиями совладающего поведения // Российский психологический журнал. - 2017. - Т. 14, № 4. - C. 180-204. DOI: 10.21702/rpj.2017.4.9

23. Борисова И. В., Зюзя А. А., Мезенцева И. А., Петухова Л. П. Особенности совладающего поведения студентов факультета физической культуры 


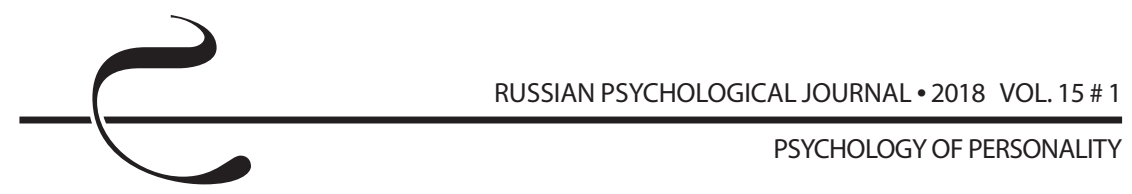

с различными уровнями тревожности // Ученые записки университета имени П. Ф. Лесгафта. - 2011. - № 10 (80). - С. 42-45.

24. Borisova I. V., Borisova U. N. Conducting Behavior Features among the Pensioners with Different Gender // International Journal of Advanced Biotechnology and Research. - 2017. - Vol. 8, Issue 3, P. 2340-2344.

25. Борисова И. В. Совладающее поведение работников поликлиники // Социальная психология личности и акмеология: сборник материалов Международной научно-практической конференции / под ред. Р. М. Шамионова, М. А. Кленовой. - М. : Перо, 2017. - С. 44-47. - URL: https:// publications.hse.ru/mirror/pubs/share/direct/211528975

26. Борисова И. В., Хулина К. И. Совладающее поведение женщин с разной сексуальной ориентацией и гендерной идентичностью // Клиническая и специальная психология. - 2017. - Т. 6, № 4. - С. 33-46. DOI: 10.17759/ cpse. 2017060403

27. Борисова И. В., Ермакова Е. С. Особенности защитного и совладающего поведения юношей и девушек // Комплексные исследования человека: психология : материалы VII Сибирского психологического форума / под ред. О. М. Краснорядцевой. - Томск : Изд-во Томского государственного университета, 2017. - Часть 2. Здоровье человека на пути к постинформационному обществу. - С. 22-25.

28. Борисова И. В., Ермакова Е. С. Защитное и совладающее поведение юношей и девушек из полных и неполных семей // Вопросы психического здоровья детей и подростков. - 2017. - № 3 (17). - С. 87-92.

29. Кулагина И. Ю., Колюцкий В. Н. Психология развития и возрастная психология. Полный жизненный цикл развития человека :Учебное пособие для вузов. - М. : Академический проект, 2015. - 420 с.

30. Хухлаева О. В., Зыков Е. В., Бубнова Г. В. Психология развития и возрастная психология : Учебник для академического бакалавриата. - Люберцы : Юрайт, 2016. - 367 с.

\section{References}

1. Freud Z. Psychology of the unconscious (Russ. ed.: Freid Z. Psikhologiya bessoznatel'nogo. Moscow, Piter Publ., 2007. 400 p.).

2. Thomas K. W. Conflict and negotiation. In: Dunnette M. D. (ed.) Handbook of industrial and organizational psychology. Palo Alto, CA, Consulting Psychologists Press, 1992, pp. 889-935.

3. Deutsch M. Sixty years of conflict. International Journal of Conflict Management, 1990, V. 1, no. 3, pp. 237-263. DOI: 10.1108/eb022682

4. Fisher R., Ury W. Getting to yes: Negotiating agreement without giving in. New York, Penguin Books, 1981 (Russ. ed.: Fisher R., Yuri U. Put'k soglasiyu, 
ili peregovory bez porazheniya. Moscow, Nauka Publ., 1992. 158 p.).

5. Antsupov A. Ya., Shipilov A. I. Konfliktologiya [Conflictology]. St. Petersburg, Piter Publ., 2013. 512 p.

6. Grishina N.V. Psikhologiya konflikta [The psychology of conflict]. St. Petersburg, Piter Publ., 2008. 544 p.

7. Freud A. The Ego and the mechanisms of defense. London, Hogarth Press and Institute of Psycho-Analysis, 1937. (Russ. ed.: Freid A. Ego i mekhanizmy psikhologicheskoi zashchity. Moscow, AST Publ., 2008. 159 p.).

8. Plutchik R., Kellerman H., Conte H. R. A structural theory of ego defenses and emotions. In: Izard C. E. (ed.) Emotions in personality and psychopathology. N. Y., Plenum Press, 1979, pp. 229-257.

9. Bassin F. V. On the power of the self and psychological defense. In: Raigorodskii D. Ya. (ed.) Samosoznanie i zashchitnye mekhanizmy lichnosti [Selfconsciousness and defense mechanisms]. Samara, Bakhrakh-M Publ., 2008, pp. 3-15.

10. Granovskaya R. M., Nikol'skaya I. M. Psikhologicheskaya zashchita u detei [Psychological defense among children]. St. Petersburg, Rech' Publ., 2010. 352 p.

11. Lazarus R. S., Folkman S. Stress, appraisal, and coping. N. Y., Springer Publishing House, 1984. 456 p.

12. Folkman S., Lazarus R. S. Coping as a mediator of emotion. Journal of Personality and Social Psychology, 1998, V. 54, Issue 3, pp. 466-475. DOI: 10.1037/0022-3514.54.3.466

13. Amirkhan J. H. A factor analytically derived measure of coping: The Coping Strategy Indicator. Journal of Personality and Social Psychology, 1990, V. 59, Issue 5, pp. 1066-1074. DOI: 10.1037/0022-3514.59.5.1066

14. Frydenberg E. Coping competencies: What to teach and when. Theory Into Practice, 2004, V. 43, no. 1, pp. 14-22.

15. Romanova E. S., Grebennikov L. R. Mekhanizmy psikhologicheskoi zashchity: genezis, funktsionirovanie, diagnostika [Psychological defense mechanisms: Genesis, functioning, and diagnostics]. Mytishchi, Talant Publ., 1996. 144 p.

16. Yaltonskii V. M., Sirota N. A. The psychology of coping: Development, advances, problems, and prospects. In: Zhuravlev A. L., Kryukova T. L., Sergienko E. A. (eds.) Covladayushchee povedenie: sovremennoe sostoyanie i perspektivy [Coping: State of the art and prospects]. Moscow, Institute of Psychology, Russian Academy of Sciences Publ., 2008, pp. 21-54.

17. Kryukova T. L., Gushchina T. V. Kul'tura, stress i koping: sotsiokul'turnaya kontekstualizatsiya issledovanii sovladayushchego povedeniya [Culture, stress, and coping: Socio-cultural contextualization of coping studies]. Kostroma, Kostroma State University Publ., 2015. 236 p. 
18. Davydova M. O., Ostapenko R. I. The relationship between optimism and coping in early adulthood. Perspektivy nauki i obrazovaniâ-Perspectives of Science and Education, 2016, V. 21, no. 3, pp. 76-81 (in Russian).

19. Gall T. L., Guirguis-Younger M. Religious and spiritual coping: Current theory and research. In: Pargament K. I., Exline J. J., Jones J.W. (eds.) APA handbooks in psychology. APA handbook of psychology, religion, and spirituality (V. 1): Context, theory, and research. Washington, DC, American Psychological Association, 2013, pp. 349-364. DOI: 10.1037/14045-019

20. Khachaturova M. R. Coping repertoire of personality: a review. Psikhologiya. Zhurnal Vysshei shkoly ekonomiki - Psychology. Journal of the Higher School of Economics, 2013, V. 10, no. 3, pp. 160-169 (in Russian).

21. Bochaver K. A., Dovzhik L. M. Coping behaviour in professional sports: phenomenology and diagnostics. Klinicheskaia i spetsial'naia psikhologiia Clinical Psychology and Special Education, 2016, V. 5, no. 1, pp. 1-18 (in Russian). DOI: 10.17759/cpse.2016050101

22. Bezuglova A. A., Vasil'eva O. S., Pravdina L. R. Socio-psychological adaptation in individuals with different coping strategies. Rossiiskii psikhologicheskii zhurnal - Russian Psychological Journal, 2017, V. 14, no. 4, pp. 180-204 (in Russian). DOI: 10.21702/rpj.2017.4.9

23. Borisova I. V., Zyuzya A. A., Mezentseva I. A., Petukhova L. P. Coping behaviour in physical education faculty students with different anxiety levels. Uchenye zapiski universiteta imeni P. F. Lesgafta, 2011, no. 10 (80), pp. 42-45 (in Russian).

24. Borisova I. V., Borisova U. N. Conducting behavior features among the pensioners with different gender. International Journal of Advanced Biotechnology and Research, 2017, V. 8, Issue 3, pp. 2340-2344.

25. Borisova I. V. Sovladayushchee povedenie rabotnikov polikliniki [Coping behaviour in polyclinic workers]. Sotsial'naya psikhologiya lichnostiiakmeologiya: sbornik materialov mezhdunarodnoi nauchno-prakticheskoi konferentsii [Proc. the International Theoretical and Practical Conference "Social psychology of personality and acmeology"]. Moscow, Pero Publ., 2017, pp. 44-47.

26. Borisova I.V., Khulina K. I. Coping behavior in with different sexual orientations and gender identity. Klinicheskaia i spetsial'naia psikhologiia - Clinical Psychology and Special Education, 2017, V. 6, no. 4, pp. 33-46 (in Russian). DOI: 10.17759/cpse.2017060403

27. Borisova I. V., Ermakova E. S. Osobennosti zashchitnogo i sovladayushchego povedeniya yunoshei i devushek [Defensive behavior and coping in young men and women]. Materialy VII Cibirskogo psikhologicheskogo foruma "Kompleksnye issledovaniya cheloveka: psikhologiya" [Proc. the VII Siberian Psychological Forum "Complex research of a man: psychology"]. Tomsk, Tomsk State University Publ., 2017, Part 2, pp. 22-25. 
28. Borisova I. V., Ermakova E. S. Defensive behavior and coping in young men and women from two-parent and one-parent families. Voprosy psikhicheskogo zdorov'ya detei i podrostkov - Mental Health of Children and Adolescent, 2017, no. 3 (17), pp. 87-92 (in Russian).

29. Kulagina I. Yu., Kolyutskii V. N. Psikhologiya razvitiya i vozrastnaya psikhologiya. Polnyi zhiznennyi tsikl razvitiya cheloveka [Developmental psychology and developmental psychology: Human full life cycle]. Moscow, Academic project Publ., 2015. 420 p.

30. Khukhlaeva O. V., Zykov E.V., Bubnova G. V. Psikhologiya razvitiya i vozrastnaya psikhologiya [Development psychology and age psychology]. Lyubertsy, Yurait Publ., 2016. 367 p. 